\title{
INTRODUCING BILINGUAL CREATIVE EDUCATION TO RUSSIAN SCHOOL CURRICULUM
}

\author{
A.V. Kharkhurin \\ American University of Sharjah \\ P.O. Box 26666 Sharjah UAE
}

\begin{abstract}
This work presents a widely discussed topic in both bilingualism and creativity research that comes from pedagogical considerations. The research conducted by the author over the last decade has delivered a solid argument that speaking more than one language facilitates an individual's creative capacities. The author has expanded the scope of his research and implemented these findings in education. His new approach includes teaching strategies from both fields, a unified Bilingual Creative Education program. The purpose of the program is to introduce students to a school curriculum in two languages and to foster their creative potential. To accomplish this goal, the program utilizes a holistic approach, which combines cognitive, personal, and environmental factors in education. The article discusses this approach and provides directions for the implementation of the program in Russia.
\end{abstract}

Key words: bilingualism, creativity, education, school, curriculum, Russia

The major theme of this work is at the intersection of two large fields of scientific inquiry: creativity and bilingualism. The research in this area is thin on the ground, since very little attention has been paid to the potential impact of bilingual practice on an individual's creative potential. In the monograph "Multilingualism and Creativity" [17], the author has presented an overview of the existing empirical studies demonstrating that both children and adults who speak more than one language have a predominant advantage over their monolingual counterparts in various creativity tests. Further, the author [20] proposed that specific structure of bilingual memory might facilitate language mediated concept activation, which in turn may ensure a simultaneous activation of often-unrelated concepts. At the same time, bilingual practice may encourage inhibition and facilitation mechanisms of selective attention. These mechanisms seem to play an important role in divergent and convergent thinking [15], and thereby foster an individual's creative performance. In addition, there is evidence that creative personality traits such as cognitive flexibility, tolerance of ambiguity, openness to new experience, and motivation can be developed as a result of bilingual practice. These cognitive mechanisms and personality traits appear to benefit from various aspects of bilingual practice such as proficiency in languages an individual uses, age of acquisition of these languages, circumstances and extent to which an individual switches between these languages, the sociocultural environment and emotional context in which these languages are acquired and used. These findings laid foundation for multilingual creative cognition paradigm [19], which unequivocally claims that bilingual development may facilitate individuals' creative potentials. This claim can have important ramifications in a context of a widely discussed topic in both multilingualism and creativity research that comes from pedagogical considerations. 


\section{History of bilingual and creative education}

The bilingual and creative aspects of education have been identified among the key directions in educational policies in many industrialized countries. For example, in a recent report to European parliaments, the Commission of European Communities [3] identified certain "key competences", which included the learning of foreign languages and development of innovation and creativity.

In the USA, bilingual education has received considerable governmental attention in the last half-century, especially as a way to teach English to recent immigrants. In 1968, the US Congress introduced the Bilingual Education Act, which was targeted directly at minority students, and has revisited that legislation on seven separate occasions. In that period, US Federal District Courts and the US Supreme Court have rendered judgments protecting the rights of language minority students [13].

Spurred by positive research findings about the use of immigrant students' home languages in education in the U.S., European states have begun to support the use of immigrant students' mother tongues because as the Commission of European Communities stated, it builds "the necessary bridge towards learning the host country language; it contributes decisively to early socialization, and to emotional and cognitive development" [4. P. 13]. Considering the tendency of bilingualism to promote linguistic and cognitive development, the acquisition of foreign languages by the native speakers of the European countries has become a primary concern of the educational programs. The European Union provides substantial financial support for foreign language learning. For example, the EU spent over $€ 30$ million a year for the Socrates and Leonardo da Vinci programs, which promote language learning and linguistic diversity. Beginning in 1989, the European Union Council issued the Common European Framework of Reference for Languages (broadened in 1996) as part of a larger project, Language Learning for European Citizenship. The Framework provides tools to assess foreign language learners' performance across Europe. In 2001, a Council Resolution recommended using this system of assessment and teaching for all language instruction in Europe. Further, to support multilingual practices, the European Union Commission for Multilingualism was established in 2007. Its purpose is to promote multilingualism by formulating language policies with a specific focus on foreign language learning. Moreover, the European Council emphasized that the target of the Council should be to promote multilingualism "by teaching at least two foreign languages from a very early age" [11. P. 19].

It should not come as a surprise that anyone with normal cognitive capacities can reach a level of accomplishment in some domain that results in producing work that some people may consider creative [1]. This means that everyone has a potential to develop creative abilities. Research supports this notion by showing that creativity can be enhanced by classroom instruction that has been carefully designed for this purpose [25]. Cropley [7] argued that all students, regardless of their intellectual aptitudes, are capable of thinking both divergently and convergently. However, as a result of experience with traditional educational systems they are more likely to think convergently; that is, to look for a single correct answer to a problem without asking "idle" questions. The reason for this behavior appears to be the nature of an educational process that stifles in many the curiosity inherent to us in childhood - when we approach adulthood, we often learn not to ask 
questions [23]. The goal of creative education therefore, is to change the existing pattern of school behavior and introduce methods and techniques that enhance students' creativity.

The importance of introducing creativity to a school curriculum has long been recognized by the academic community. L. Vygotsky believed that "we should emphasize the particular importance of cultivating creativity in school-age children" [31. P. 87]. He argued that creativity was the most crucial factor contributing to the future development of the human race. As school prepares children for the future, the "development and exercise of the imagination should be one of the main forces enlisted for the attainment of this goal" [31. P. 88]. In his American Psychological Association presidential address, Guilford [14] expressed particular concerns that the school curriculum discourages school-age children from developing their creative potential. Torrance [29] validated this concern by providing empirical evidence from longitudinal studies that half of the students he studied revealed a "fourth-grade slump" in divergent thinking. Runco [26] picked up on this debate by arguing that this drop in the creative behavior of young children may reflect the expectations and pressures to conform that characterize many educational settings. In spite of these and many other concerns raised by the academic community, schools seem to express little interest in fostering creativity. Rather, it is quite evident that schools use any opportunity to reduce the creative potential of students and make every possible effort to suppress creative activity in the classroom. Teachers' attitudes and methods generally adopted in standard education provide little opportunity for the flourishing of creative potential in the school settings. Students learn conformity instead of innovativeness; they develop habitual behavior to comply with the system rather than to critically evaluate it.

The prudence of introducing creative education has also gradually gained support in some governments' policies. Policymakers recognize creative education as a potential investment in their students' and country's future. Craft [6] (2007) reports that starting in the 1990s legislators from around the globe (Australia, Canada, China, Europe, Hong Kong, the Middle East, and Singapore) began to endorse initiatives facilitating the development of students' creative potential. For example, the United Kingdom witnessed a revival of a discourse on the role of creativity in society and economy [5]. In the late 1990s, the National Endowment for Science, Technology and the Arts and the National Advisory Committee on Creative and Cultural Education were established. Their goals are to identify and fund creativity and innovation in different areas of human endeavor, and to carry out research and evaluation focusing on these skills. The Department for Education and Employment/Qualifications and Curriculum Authority identified creative thinking as a key skill in the National Curriculum $[9 ; 10]$. This initiative entailed the launching of a number of projects and policies with the focus on introducing creativity to the school curriculum (e.g., Creativity: Find it, Promote it!', Excellence in Cities, Excellence and Enjoyment) as well as establishing funds encouraging teachers' creativity and thinking (e.g., Best Practice Research Scholarships and Professional Bursaries; see Craft [5], for details). In the same vein, in the communication from the Commission of European Communities, the role of creative education in the progress of the European Union was stressed explicitly: "To achieve this it is crucial fully to develop the potential for innovation and creativity of European citizens. The education element of the knowledge triangle 
'research-innovation-education' should be strengthened, starting early — in schools” [3. P. 3].

Since Guilford's [14] seminal presidential address to the American Psychological Association, numerous studies have aimed at identifying and studying creativity. Creativity was proclaimed as a necessary component of intellectual, economic and social progress [8]. Unfortunately, quite often the governmental initiatives encouraging creative education are driven by market-related motivations and do not take the realities of the classroom into account. These externally imposed policies encouraging creative education place teachers between two seemingly contradictory demands. On one side, they are overwhelmed by initiatives fostering creativity; on the other, they are restricted by requirements to provide a curriculum that ensures their students' successful performance on standard examinations. As a result, despite the apparent limitations of standard educational programs and the findings of empirical investigations that reveal these drawbacks, individuals and institutions continue to invest in core subject skills (such as literacy, math, etc.) rather than in creative skills. Contemporary education is reluctant to make radical changes in its philosophy and goals to substitute a standard education with a creative one. However, the time is ripe for integrating the nurturing of creative skills into the curriculum. Combining language learning and creativity fostering strategies may be precisely one way to accomplish this.

\section{Bilingual and creative education united}

So far, we have discussed two types of educational programs: some fostering language learning and others intended to facilitate students' creative capacities. It is evident that the creativity fostering programs operate separately from those offering bilingual instruction, and researchers and teachers have mutually exclusive training. They are educated in either creativity or language related disciplines. Recall from the previous discussion that the academic community generally disregards the potential relationship between bilingualism and creativity. Similarly, the benefits of merging programs fostering creative potential and bilingual abilities seem to be disregarded by educators. However, the efficacy of a program combining both efforts can be directly inferred from the research presented in the beginning of this article $[17 ; 19 ; 20]$. Bilingualism was found to facilitate certain cognitive processes underlying an individual's creative performance. Therefore, by combining bilingual and creative education, a far greater synergy could be generated a bilingual creative education program would capitalize on the assets of both forms of education to establish an effective and comprehensive curriculum. This section elaborates on this idea and presents future directions for research in bilingual creative education.

The Bilingual Creative Education (BCE) program constitutes a unified teaching model that introduces both language learning and creativity-fostering instructions to the school curriculum. The rationale is not to establish a special program focusing on children with exceptional abilities, but to suggest modifications to existing curricula and/or the classroom environment to promote bilingualism and creativity in early schooling. The need for this type of program is immense, considering the outcomes of scientific investigation, initiatives advanced by governmental policies, and public opinion. As discussed earlier, an expanding body of empirical research emphasizes the positive role of bilingualism in fostering creative potential. This research confirms a commonsense perspective expressed by laypersons 
regarding the relationship between bilingualism and creativity. For example, the European Commission has commissioned a study on the contribution of multilingualism to creativity [21]. The results of the survey revealed that people believed that multilingualism increases the capacity for original and abstract thinking and facilitates flexibility in thinking and reasoning outside the box. They also thought that multilingualism fosters interpersonal communication skills and stimulates one's ability to learn other languages. The recommendation of that study to the European Union calls for developing a program that focuses on both bilingual and creative education. This recommendation echoes the goals articulated during the European Year of Creativity and Innovation (2009). These goals highlight the role of creativity, innovation, and bilingualism in stimulating educational practices aiming at enhancing personal, social and economic development. More importantly, the conclusion of that study emphasizes the role of bilingualism in learning other subjects, which has particular significance for the present discussion. Introducing $\mathrm{BCE}$ to the school curriculum may have an added value - it may provide auxiliary advantages for a wide range of academic endeavors.

The BCE program rests on a four-criterion construct of creativity that includes novelty, utility, aesthetics and authenticity (see the author's work [18], for a detailed discussion). In contrast to a traditional view that creativity involves a combination of novelty and utility, this program assumes that successful creative functioning is stipulated by all four aspects of creativity. Therefore, this program fosters aesthetic and authentic aspects in addition to originality and appropriateness. The BCE program is grounded on several conceptual premises. First, the BCE program disqualifies the elitist view and provides opportunities to enhance the linguistic and creative capacities of all students regardless of their intellectual and creative predispositions. This entails the second characteristic of the program, its scope of application - the BCE can be implemented in any school curriculum, depending on the specific details of a given school. The role of the program coordinator would be to modify the core of the program to reflect the specificity of the student body and the economic, sociocultural and political environment of each particular school. Instead of establishing a new school or a special classroom with an entirely new curriculum, this program suggests necessary modifications to convert any curriculum into one fostering bilingual abilities and creative potential. Therefore, it reflects the recommendations of certain governmental policies that methodologies should be developed to modify and improve the effectiveness of existing educational programs. Moreover, these modifications can be accomplished at a low cost because they would not require major restructuring of existing school curricula. Third, the goal of the BCE program is to facilitate bilingual learning in a diversity of student populations. This program is designed not only for migrants who speak their native language and who are attempting to acquire the language of the country to which they have migrated. It is conceived for all children, immigrants as well as those who want to acquire an additional language. Fourth, another goal of the program is to foster children's creative potential. The focus of the program is not on bigger-C creativity, but on the smaller-c creative capacities (cf., [16]) that are grounded in mundane cognitive functioning and can be applied to everyday problem solving. The outcomes of this program do not reflect the ambitious aspirations of nurturing eminent individuals (although, this perspective should not be excluded). Rather, the program aims at facilitating the overall linguistic, intellectual, 
and creative competences of young children, thereby meeting the recommendations of certain governmental policies (e.g., Commission of European Communities [3]). Finally, the BCE program in its present state is conceived for elementary schools, for these are the crucial years in a child's linguistic and cognitive development.

\section{BCE attributes}

Thus, the purpose of the BCE program is to introduce students to two languages and to foster the four defining aspects of creativity: novelty, utility, aesthetics, and authenticity. To accomplish this goal, the program utilizes a holistic approach that combines cognitive, personal, and environmental factors. This approach considers not only educational aspects directly pertinent to the school curriculum, but also those reflecting a child's personality and extracurricular settings. This section presents a sketch of five essential attributes of the $\mathrm{BCE}$ that reflect intrapersonal, interpersonal and environmental factors. These attributes (curricular, personal, cognitive, administrative, and environmental) were adopted from various studies in bilingual, as well as creative education $[2 ; 8 ; 12 ; 22 ; 24$; 28]. The presentation of these attributes in the current work intends to stimulate the creative thinking in education professionals rather than to provide an explicit step-bystep description of the program. I pinpoint the essential attributes and direct the interested reader to the monograph "Multilingualism and Creativity" [12], which presents a detailed description as well as theoretical and empirical considerations underlying the program.

Curricular attributes. The foremost set of attributes describes the essential characteristics of the curriculum constituting the BCE program. It is important to note that the program does not intend to replace the existing school curriculum, but rather to modify it by incorporating new elements pertinent to bilingual and creative education. The following curricular attributes should be considered:

1) The program uses current teaching strategies, but presents the academic curriculum through two languages;

2) The program adapts the existing school curriculum to the diversity of languages and cultures of the students. This process can be facilitated by employing teachers with various linguistic and cultural backgrounds and consultations with parents and local community members;

3) The program utilizes student-directed instructional strategies enhancing their linguistic and creative abilities. It adopts an open teaching and learning approach [30] that provides essential conditions for enhancing students' performance;

4) The program establishes a balanced curriculum that includes both basic and higherorder knowledge and skills; the latter presenting a necessary condition for the development of creative potential. A solid background in fundamental ideas in languages, arts and sciences appears essential in developing domain-specific ones (e.g., poetry, visual art, music, design, chemistry, mathematics, and physics);

5) To successfully screen students' development, the program incorporates a systematic student assessment. The assessment does not aim at the evaluation and judgment of students' accomplishments, but rather at monitoring their performance in order to employ more efficient schooling strategies;

6) The program encourages teachers to innovatively organize the classroom environment, which has an impact on creative thinking. The teachers make an additional 
effort to create a student friendly microclimate in the classroom. In this regard, teachers are advised to introduce basic meditation practices to establish the spiritual foundation of the class, to reduce stress, and to increase students' language learning, and cognitive and creative functioning;

7) The program expands the roles and responsibilities of teachers by providing them with more decision-making power when it comes to the choice of curriculum and instructional strategies.

Personal attributes. The program aims at developing personality traits that, on the one side, encourage students to engage in the bilingual creative educational process, and, on the other, facilitate their bilingual and creative practices. The following personal attributes should be considered:

1) It is important to instill in students a firm sense of the purpose and intent of this education;

2) The program strives to build motivation, especially intrinsic motivation;

3) The program fosters openness to new ideas and experiences by stimulating and rewarding curiosity, exploration, and adventurousness;

4) The program instills in students a tolerance for ambiguity, which is considered an important factor in an individual's creative behavior;

5) The program encourages autonomy, positive self-evaluation, and high self-esteem. Confidence comes with successful experience. Therefore, it is essential to create an environment that encourages and rewards students' effort per se;

6) Although competition might be effective under certain circumstances, it often reduces creative tendencies. The program therefore encourages self-improvement and self-comparison rather than "winning" and outperforming others;

7) Special attention is given to the development of an aesthetic sense in students. One of the schooling objectives is to train the students to distinguish between creative solutions of different aesthetic value. The aim of the program is to enable students to develop understanding and intuition not only for hard evidence readily available to the beholder, but also for more subtle nuances underlying beauty and the truth.

Cognitive attributes. The program aims to foster those cognitive abilities that facilitate students' language acquisition and help develop their creative potential. The following cognitive attributes should be considered:

1) The program builds a fund of general knowledge and basic skills similar to a traditional school curriculum. In contrast to traditional education, curricular material is presented in two languages thereby providing more opportunities for elaborative rehearsal;

2) The program encourages the acquisition of domain-specific knowledge. Students build specific knowledge base and area-specific skills;

3) The program teaches the kind of convergent thinking that is manifested in the ability to analyze and synthesize information. Students acquire skills in seeing connections, overlaps, similarities and logical implications;

4) The program teaches the sort of divergent thinking that is manifested in the ability to simultaneously process several pieces of information;

5) The program encourages students to employ strategies exercising their capacities to construct new conceptual plans rather than to rely on existing knowledge;

6) The program teaches students not only problem solving, but also problem finding; 
7) Metacognitive skills such as self-evaluation and self-management appear to be invaluable capacities in both language learning and creative behavior. The program provides opportunities for students to identify under what conditions they can most effectively employ their metacognitive skills.

Administrative attributes. The program proposes a set of administrative modifications that can be utilized in BCE as well as in schools with traditional curriculum. The following administrative attributes should be considered:

1) The program requires an innovative leadership;

2) The program incorporates an option to customize the learning environment that reflects the goals of the students and community as well as the economic, sociocultural, and political aspects of the environment;

3) The program recognizes that attitudes, beliefs, assumptions, and expectations of a triad of teachers, students, and parents have powerful influence on students' learning opportunities and outcomes. It emphasizes the importance of a supportive school-wide climate for effective implementation of the program;

4) The program strives to establish a bond between a group of teachers and a group of students by organizing them in continuous clusters. In addition, the program introduces measures to group students more flexibly to respond to their developmental differences during the entire period of schooling;

5) Ongoing professional staff development constitutes an important component of effective program delivery;

6) The program protects and extends instructional time to multiply the opportunities for students to engage in academic learning;

7) The program assumes articulation between schooling modules and coordination between schools utilizing BCE.

Environmental attributes. The curricular, personal, cognitive, and administrative attributes discussed so far do not present a complete picture of the program, because those aspects evolve as a result of the interaction with the environment. The success of the program largely depends on what environmental factors are present: discouraging or stimulating and inspiring, inhibiting or nurturing and cultivating. The following environmental attributes should be considered:

1) The program develops a coherent sense of the students and what they hope to accomplish;

2) The program ensures that the behavior of a student is accepted with tolerance, and approval of creative urges;

3) The program provides opportunities for the practice of acquired abilities outside the school curriculum;

4) The program adapts to mobility and special non-school needs of students and families;

5) The program involves parents and their community in their children's education;

6) The program combines the efforts of school staff and social service agencies to modify (if necessary) the schooling context to address students' social and emotional needs;

7) The program utilizes available resources in highly coordinated ways. The objective of the program is to allocate additional resources to secure a prolific learning environment. 


\section{Directions for the implementation of the Bilingual Creative Education program in Russia}

The description of the BCE program presented in the previous section is strictly theoretical. To study the program's implications in students' language acquisition and creative performance, it should be implemented in schools with different linguistic and sociocultural characteristics. I propose a pilot project in Russia to study teaching methods and strategies that would encourage students' foreign language learning and foster their creative capacities. The pilot group would consist of eight $5^{\text {th }}$ grade Russian-English bilingual school students (and another eight control group students matching the pilot group in age and creative, cognitive and linguistic capacities). The program will be delivered to this group by a BCE team consisting of a professional teacher and two teacher's assistants, all fluent in Russian and English. The team will undergo special training, which allows them to deliver the BCE program in two languages in a manner fostering students' creative capacities. Note that this program complements the standard curriculum, and does not substitute it. The program will be offered in the form of an intervention program for a period of 12 months, two hours twice a week. It combines individual computerbased activities with in-class group activities.

Recall that the aim of the program is not to foster artistic skills (e.g., music, painting), which should be developed in special courses. Rather, it strives to foster creative capacities in everyday life. Therefore, it uses the following teaching approach. As a vantage point, it uses the factual knowledge acquired in school in various subjects (e.g., math, physics, chemistry, literature, history). It applies five major creativity fostering strategies (problem finding, divergent thinking, brainstorming, SCAMPER, and attribute listing; [27]) to that knowledge.

To ensure bilingual disposition of the program, the BCE activities strive to encourage students to use both English and Russian in the schooling context. To ensure full linguistic immersion, the instructions and teaching materials are given in one language (English) during the first hour and in another language (Russian) during the second hour. All creativity fostering strategies imply group activities, which require oral use of both languages. At the end of each class, students receive homework, which involves written assignments in both languages. These assignments are discussed in the following class.

Overall, the BCE teaching strategies are expected a) to improve an overall schooling process, $b$ ) to foster students' creative potential, and c) to enhance students' linguistic abilities. The first goal is accomplished by using material studied in the core curriculum. Students in the BCE program deal with the same material they have already studied, but in a more elaborate and game-like manner. This improves their understanding and retention of the material, which eventually results in better school performance. The second goal is accomplished by intensive use of creativity fostering techniques. The third goal is accomplished by increasing students' motivation to use both languages in the academic environment. Motivation was shown to play a crucial role in both successful language learning and prolific creative behavior. In the BCE class, the students learn to use both English and Russian in solving interesting and game-like problems. In turn, this increases their motivation to improve their linguistic skills.

To assess the program's success, a system of students' performance assessment was designed. Note that the assessment does not aim to evaluate or judge students' 
accomplishments. Rather, it aims to monitor students' performance in order to supply the empirical data for the project. This incentive requires more authentic assessment tools and scoring rubrics. The BCE identifies four groups of assessment that serve the following purposes: identification, placement, progress, and achievement. The identification assessment is administered in the form of surveys when students registered in the program. This assessment collected general information about students' cultural and linguistic background and their creative attitudes. The placement assessment determines students' creative potential and mastery of English and Russian. The progress assessment is an ongoing evaluation that intends to monitor students' linguistic, cognitive, and creative development as they progress through the program. This assessment is administered every two months. The achievement assessment is used to identify whether students' outcomes satisfy linguistic, creative and academic expectations. This assessment is administered at the end of the project.

\section{Conclusion}

The major goal of this article was to expand the boundaries of contemporary discourse of education and combine the bilingual approach to education with the creative one. It is evident that the academic community generally disregards the potential relationship between bilingualism and creativity. Similarly, the benefits of merging programs fostering creative potential and bilingual skills seem to escape the attention of educators. However, the efficacy of the programs combining both efforts can be directly inferred from contemporary research. Bilingualism was found to facilitate certain cognitive functions underlying an individual's creative performance. Therefore, by combining bilingual and creative trainings, a far greater synergy could be created: a bilingual creative education program would capitalize on the assets of both forms of education to establish an effective and comprehensive curriculum.

In this regard, it is important to recognize that the essential attributes of the BCE discussed in this paper provide the theoretical framework of the program rather than practical suggestions for the program's design and implementation. Before this program gains enough power to suggest modifications to the educational system at large, it should pass through the cycles of empirical validation. The author proposes the first cycle, which aims at implementing the BCE methodology with school students in Russia, and at empirically investigating the impact of the program on students' academic, linguistic, and creative performance. At the end of this project, it is expected to obtain measurable empirical support for the BCE program, to compile a BCE manual with guidelines on how to implement the program and to suggest modifications to the existing educational system so that it encourages multilingual upbringing and stimulation of students' creative capacities.

Thereby, several critical questions could be answered. Is it feasible to implement this program in regular schools? The objective of the program constitutes modifications to existing curricula aimed at fostering the bilingual and creative practices of the students. Considering the innovative nature of this program it is important to make a conclusive decision as to whether this method is, in principle, realistic. An answer to this question can be inferred from two other questions: would BCE students demonstrate an increase in their linguistic and creative performances, and more importantly, would BCE students 
demonstrate significant differences with their counterparts from schools with traditional education in their academic, linguistic, and creative achievements? The answer to these questions will be obtained through administering a systematic assessment of students' language skills and creative abilities at the end of the pilot study. While implementing the program, another issue pertinent to special training for the school staff needs to be accounted for. The BCE program requires innovative teaching approaches in both delivering the curriculum and establishing a stimulating and facilitating educational climate. Although many teachers may favor these approaches in principle, they might not have sufficient knowledge and skills to implement these ideas in practice.

In sum, investing in the $\mathrm{BCE}$ is a riskier enterprise than supporting literacy and other skills tied to traditional education. Despite the less certain payoffs, this new form of education promises to have important ramifications for students' learning and their future employment. It is important for educators to recognize the positive effect of bilingual creative education and to start transforming schools into educational enterprises that value linguistic and cultural diversity and creative potential.

\section{REFERENCES}

[1] Amabile T.M. The social psychology of creativity. New York: Springer-Verlag, 1983. 246 p.

[2] August D., Hakuta K. Improving schooling for language-minority children: A research agenda. Washington, DC: National Academy Press, 1997. 504 p.

[3] Commission of European Communities. Improving competences for the 21st century: An agenda for European cooperation on schools Communication from the Commission to the European Parliament, the Council, the European Economic and Social Committee and the Committee of the Regions. Brussels, 2008. $12 \mathrm{p}$.

[4] Commission of European Communities. Results of the consultation on the education of children from a migrant background Commission Staff Working Document. Brussels, 2009. 36 p.

[5] Craft A. Creativity in schools: Tensions and dilemmas. London, UK: Routledge, 2005. 224 p.

[6] Craft A. Possibility thinking in the early years and primary classroom. In: A.-G. Tan (Ed.), Creativity: A handbook for teachers. Singapore: World Scientific, 2007, pp. 231-249.

[7] Cropley A.J. More ways than one: Fostering creativity. Westport, CT US: Ablex Publishing, 1992. $132 \mathrm{p}$.

[8] Cropley A.J. Creativity in education \& learning: A guide for teachers and educators. London, UK: Kogan Page, 2001. 208 p.

[9] Department for Education and Employment/Qualifications and Curriculum Authority. The National Curriculum handbook for primary teachers in England. London, 1999. 152 p.

[10] Department for Education and Employment/Qualifications and Curriculum Authority. The National Curriculum handbook for secondary teachers in England. London, 1999. 223 p.

[11] European Council. Presidency conclusions. Barcelona, 2002. 72 p.

[12] Feldhusen J.F., Kolloff M.B. A three-stage model for gifted education. Gifted Child Today, 1978, vol. 1, pp. 3-5, 53-57.

[13] Garcia E.E. Bilingual education in the United States In: J. Altarriba, R.R. Heredia (Eds.), An introduction to bilingualism: Principles and processes. Mahwah, NJ: Lawrence Erlbaum Associates Publishers, 2008, pp. 321-343.

[14] Guilford J.P. Creativity. American Psychologist, 1950, vol. 5, pp. 444-454.

[15] Guilford J.P. The Nature of Human Intelligence. New York: McGraw-Hill, 1967.

[16] Kaufman J.C., Beghetto R.A. Beyond big and little: The four c model of creativity. Review of General Psychology, 2009, vol. 13, pp. 1-12.

[17] Kharkhurin A.V. Multilingualism and Creativity. Bristol, UK: Multilingual Matters, 2012. 240 p. 
[18] Kharkhurin A.V. Creativity.4in1: Four-criterion construct of creativity. Creativity Research Journal, 2014, vol. 26, pp. 338-352.

[19] Kharkhurin A.V. Multilingual creative cognition: Theory and practice. In R. Jones (Ed.), Routledge Handbook of Language and Creativity (pp. 452-466). London, UK: Routledge, 2015.

[20] Kharkhurin A.V. Multi-competence as a creative act: Ramifications of multi-competence paradigm for creativity research and creativity fostering education. In V. Cook \& W. Li (Eds.). Cambridge Handbook of Linguistic Multi-competence (pp. 420-444). Cambridge, UK: Cambridge University Press, 2016. DOI: 10.1017/CBO9781107425965.020

[21] Marsh D., Hill R. Study on the Contribution of Multilingualism to Creativity. Final Report. Brussels: European Commission, 2009. 24 p.

[22] McLeod B. School reform and student diversity: Exemplary schooling for language minority students. Washington, DC: George Washington University: Institute for the Study of Language and Education, 1996. 70 p.

[23] Nickerson R.S. Enhancing creativity. In: R.J. Sternberg (Ed.), Handbook of creativity. New York, NY: Cambridge University Press, 1999, pp. 392-430.

[24] Nickerson R.S., Sternberg R.J. The teaching of thinking and problem solving. Thinking and problem solving. San Diego, CA US: Academic Press, 1994, pp. 409-449.

[25] Perkins D.N., Laserna C. Inventive thinking. In: M.J. Adams (Ed.), Odyssey: A curriculum for thinking. Watertown, MA: Mastery Education Corporation, 1986.

[26] Runco M.A. Creativity. Annual Review of Psychology, 2004, vol. 55, pp. 657-687.

[27] Starko A.J. Creativity in the classroom: Schools of curious delight $/ 4^{\text {th }}$ ed. New York, NY: Routledge, 2010. $356 \mathrm{p}$.

[28] Thomas W.P., Collier V.P. A national study of school effectiveness for language minority students' long-term academic achievement. Final Report. Berkeley, CA: Center for Research on Education, Diversity \& Excellence, University of California, 2000. 8 p.

[29] Torrance E.P. A longitudinal examination of the fourth grade slump in creativity. Gifted Child Quarterly, 1968, vol. 12, pp. 195-199.

[30] Urban K.K. Openness: A "magic formula" for an adequate development and promotion of giftedness and talents?! Gifted and Talented International, 1995, vol. 10, pp. 15-19.

[31] Vygotsky L.S. Imagination and creativity in childhood. [Воображение и творчество в детском возрасте]. Journal of Russian and East European Psychology, 1967/2004, vol. 42, pp. 7-97.

\title{
ВВЕДЕНИЕ ПРОГРАММЫ БИЛИНГВАЛЬНОГО И ТВОРЧЕСКОГО ОБРАЗОВАНИЯ В УЧЕБНЫЙ ПЛАН РОССИЙСКИХ ШКОЛ
}

\author{
А.В. Хархурин \\ Американский университет Шарджи \\ P.O. Вох 26666, Шарджа, ОАЭ
}

В данной статье представлена проблема, широко обсуждаемая как в исследованиях билингвизма, так и в исследованиях творческих процессов, рассматриваемая с точки зрения ее педагогических приложений. Исследования, проведенные автором в последние десятилетия, убедительно доказывают, что владение более чем одним языком способствует развитию твор- 
ческих способностей человека. Автор расширил сферу своих исследований и применил их результаты в области образования. Предлагаемый авторский новый подход объединяет стратегии обучения, используемые в обеих областях (билингвизм и творчество), в единой программе билингвального и творческого образования. Целью программы является преподавание дисциплин на двух языках и развитие творческого потенциала школьников. Для достижения этой цели программа использует комплексный подход, который объединяет когнитивные, личностные и средовые факторы образования. В статье обсуждается данный подход и предлагаются направления для реализации предлагаемой программы в России.

Ключевые слова: билингвизм, творчество, образование, школа, учебный план, Россия

Поступила в редакцию 17.09.2016

Принята к печати 14.10.2016 